\title{
Evaluation of Dried and Wet Distillers Grains Included at Two Concentrations in the Diets of Lactating Dairy Cows ${ }^{1}$
}

\author{
J. L. Anderson, D. J. Schingoethe, ${ }^{2}$ K. F. Kalscheur, and A. R. Hippen \\ Dairy Science Department, South Dakota State University, Brookings 57007-0647
}

\begin{abstract}
The purpose of this study was to determine the lactation performance of dairy cows fed dried or wet distillers grains (DG) with solubles (DDGS or WDGS) at 2 dietary concentrations. A trial using 15 cows was designed as a replicated $5 \times 5$ Latin square with periods of $4 \mathrm{wk}$ each and data collected during wk 3 and 4 of each period. Diets, on a dry matter basis, were: control, $10 \%$ DDGS, 20\% DDGS, 10\% WDGS, and 20\% WDGS. All diets contained $25 \%$ corn silage, $25 \%$ alfalfa hay, and $50 \%$ of the respective concentrate mixes. Dry matter intake (DMI) tended to be greater for cows fed control than DG $(23.4,22.8,22.5,23.0$, and $21.9 \mathrm{~kg} / \mathrm{d}$ for control, $10 \%$ DDGS, 20\% DDGS, 10\% WDGS, and 20\% WDGS). Milk yield (39.8, 40.9, 42.5, 42.5, and $43.5 \mathrm{~kg} / \mathrm{d}$ ) was greater for cows fed DG than control. Milk fat percentage $(3.23,3.16,3.28,3.55$, and $3.40 \%)$ was similar for cows fed control and DG, but greater for cows fed WDGS than DDGS. Milk fat yield was greater for cows fed DG than control and tended to be greater for cows fed WDGS than DDGS. Milk fat from cows fed DG, especially $20 \%$ DG, was more unsaturated and contained more cis-9, trans-11 conjugated linoleic acid than when fed the control diet. Milk protein percentage (3.05, 3.01, $3.02,3.11$, and $3.06 \%$ ) was similar for cows fed control and DG but greater for cows fed WDGS than DDGS. Milk protein yield was greater for cows fed DG than control, tended to be greater for cows fed WDGS than DDGS, and tended to be greater for cows fed 20\% DG than $10 \%$ DG. Milk urea nitrogen was similar for cows fed control and DG but greater for cows fed WDGS than DDGS and tended to be higher for cows fed $20 \%$ DG than $10 \%$ DG. Ruminal ammonia concentrations were greater for cows fed WDGS than DDGS. Overall, feeding DG improved feed efficiency $(1.70,1.79,1.87,1.84$, and $1.92 \mathrm{~kg}$ of energy-corrected milk/kg of DMI) by
\end{abstract}

\footnotetext{
Received September 2, 2005.

Accepted February 24, 2006.

${ }^{1}$ Published with the approval of the director of the South Dakota Agricultural Experiment Station as Publication Number 3511 of the Journal Series.

${ }^{2}$ Corresponding author: david.schingoethe@sdstate.edu
}

increasing yields of milk, protein, and fat while tending to decrease DMI.

Key words: dried distillers grains, wet distillers grains, lactating dairy cow

\section{INTRODUCTION}

When feeding distillers grains (DG) to dairy cattle there are several concerns, 2 of which are what form (wet or dried) to feed, and how much DG can be included in the ration. The form of DG with solubles, meaning wet DG with solubles (WDGS) or dried DG with solubles (DDGS) may affect animal performance when fed to lactating dairy cows because there is the possibility of heat damage during the drying of DDGS, and this may have effects on digestibility and use of nutrients (Powers et al., 1995). When WDGS is fed, the greater concentration of water in diets may decrease DMI (Lahr et al., 1983; Hippen et al., 2003). Several experiments (Nichols et al., 1998; Liu et al., 2000; Schingoethe, 2001) indicated that wet and dried DG can be effectively fed at $20 \%$ of ration DM; however, many nutritional consultants do not routinely recommend feeding that much. Wet DGS was well utilized at $31 \%$ of diet DM (Schingoethe et al., 1999) with a slight decrease in DMI. In other studies, the moisture content added to the diet by feeding WDGS at 30 or $40 \%$ of DM might have contributed to decreased DMI and milk production (Hippen et al., 2003; Kalscheur et al., 2004). Gut fill was not a problem when diets contained more than $20 \%$ of DM as DDGS, but there was no advantage to feeding more than $25 \%$ of DM as DDGS (Hippen et al., 2004). Most studies have fed only WDGS or DDGS and often at only one concentration of the ration. Only one study was found, with lactating cows that compared the feeding of wet and dried DG (Al-Suwaiegh et al., 2002), although WDGS and DDGS have been compared in diets of growing ruminants (Ham et al., 1994). When fed at $15 \%$ of ration DM, both wet and dried DG supported similar milk production, composition, and DMI (Al-Suwaiegh et al., 2002). With this previous research in mind, the objective of this study was to evaluate and compare the use of WDGS and DDGS at 2 concentrations (10 and $20 \%$ of ration DM) in the diets of lactating dairy cows based on milk yield, composition, and feed intake. 
Table 1. Formulations for the control, 10\% dried distillers grains with solubles (DDGS), 20\% DDGS, 10\% wet distillers grains with solubles (WDGS), and 20\% WDGS treatment diets fed during the lactation study

\begin{tabular}{|c|c|c|c|c|c|}
\hline \multirow[b]{2}{*}{ Item } & \multicolumn{5}{|c|}{ Diet } \\
\hline & Control & $\begin{array}{l}10 \% \\
\text { DDGS }\end{array}$ & $\begin{array}{l}20 \% \\
\text { DDGS }\end{array}$ & $\begin{array}{l}10 \% \\
\text { WDGS }\end{array}$ & $\begin{array}{l}20 \% \\
\text { WDGS }\end{array}$ \\
\hline & \multicolumn{5}{|c|}{$\longrightarrow(\%$ of DM $)$} \\
\hline Corn silage & 25.0 & 25.0 & 25.0 & 25.0 & 25.0 \\
\hline Alfalfa hay & 25.0 & 25.0 & 25.0 & 25.0 & 25.0 \\
\hline Corn, ground & 35.6 & 31.3 & 26.7 & 31.3 & 26.7 \\
\hline Soybean meal, $44 \% \mathrm{CP}$ & 12.5 & 7.0 & 1.6 & 7.0 & 1.6 \\
\hline DDGS & 0.0 & 10.0 & 20.0 & 0.0 & 0.0 \\
\hline WDGS & 0.0 & 0.0 & 0.0 & 10.0 & 20.0 \\
\hline Salt & 0.53 & 0.53 & 0.53 & 0.53 & 0.53 \\
\hline Magnesium oxide & 0.05 & 0.05 & 0.05 & 0.05 & 0.05 \\
\hline Limestone & 0.82 & 0.82 & 0.82 & 0.82 & 0.82 \\
\hline Dicalcium phosphate & 0.22 & 0.00 & 0.00 & 0.00 & 0.00 \\
\hline Dairy Micro premix ${ }^{1}$ & 0.25 & 0.25 & 0.25 & 0.25 & 0.25 \\
\hline Vitamin E premix ${ }^{2}$ & 0.07 & 0.07 & 0.07 & 0.07 & 0.07 \\
\hline
\end{tabular}

${ }^{1}$ Dairy Micro premix (Land O’Lakes, St. Paul, MN): 10\% Mg; 2.6\% Zn; 1.7 ppm Mn; 4,640 ppm Fe; 4,712 ppm Cu; 396 ppm I; 119 ppm Co; 140 ppm Se; 2,640,000 IU/kg vitamin A; 528,000 IU/kg vitamin $\mathrm{D}_{3}$; and $10,560 \mathrm{IU} / \mathrm{kg}$ vitamin $\mathrm{E}$.

${ }^{2}$ Vitamin E premix: 44,000 IU/kg.

\section{MATERIALS AND METHODS}

Ten multiparous and 5 primiparous Holstein cows, averaging $73( \pm 26)$ DIM, were used in an experiment to evaluate both WDGS and DDGS fed at 2 diet concentrations. Cows were assigned to 1 of 5 experimental diets in a replicated $5 \times 5$ Latin square design. Cows were blocked by parity, production, and DIM, and assigned to treatment diets at random. Cows were housed in a free-stall barn and fed diets as a TMR with a Calan Broadbent feeder door system (American Calan, Inc., Northwood, NH). Diets were fed once daily $(0800 \mathrm{~h})$ in amounts to allow for ad libitum consumption and animals were allowed access to feed at all times, except during milking. Cows were milked 3 times daily at 0600, 1400 , and $2100 \mathrm{~h}$, and daily milk production was recorded. Before the start of the study, there was a 10-d adaptation period for cows to adjust to the Calan feeding system followed by the 5 feeding periods. Each period was 4 wk long; the first 2 wk were for adjustment to treatment diets, and wk 3 and 4 for data collection. Animal care and use was according to a protocol approved by the South Dakota State University Institutional Animal Care and Use Committee.

The 5 treatment diets were: control, $10 \%$ dried distillers grains (10\% DDGS), $20 \%$ dried distillers grains (20\% DDGS), $10 \%$ wet distillers grains (10\% WDGS), and $20 \%$ wet distillers grains (20\% WDGS). Both forms of distillers grains contained solubles, and were purchased from the same vendor to ensure similarity of composition. Diets (see Tables 1 and 2) were formulated to contain $17 \% \mathrm{CP}$ using corn and soybean meal as the base of the concentrate mix, with DG replacing a portion of these ingredients in the 10 and $20 \%$ treatment diets. Diets were formulated to meet or exceed the requirements for a mature, lactating Holstein cow, of $680 \mathrm{~kg}$ $\mathrm{BW}$, at $90 \mathrm{DIM}$, and producing $47 \mathrm{~kg}$ of milk, according to the 2001 dairy NRC. However, RUP was slightly less and NFC was slightly more than recommended. When formulating it was assumed that the 2 distillers grains were the same except for DM, in an effort to minimize differences between ingredients in the base diets and to ensure that a direct comparison of the 2 DG was being made. The average of the components of the 2 DG from analysis given by the manufacturer was used for formulation. All diets contained $25 \%$ alfalfa hay and $25 \%$ corn silage. Forages were premixed in a mixer wagon. The concentrate mix was added to the Calan Data Ranger (American Calan, Inc.) after addition of the premixed forages. The DDGS were mixed into concentrate mixes at the South Dakota State University Feed Mill. For WDGS diets, the portion of WDGS was mixed into the TMR with other ingredients using the Data Ranger. Therefore, the control TMR, 10\% DDGS TMR, and 20\% DDGS TMR contained $50 \%$ respective concentrate mixes and $50 \%$ forage mix, the 10\% WDGS TMR contained $10 \%$ WDGS, $40 \%$ concentrate mix, and $50 \%$ forage mix, and the 20\% WDGS TMR contained $20 \%$ WDGS, $30 \%$ concentrate mix, and $50 \%$ forage mix as percentages of DM.

Feed intake for individual cows was measured daily using the Calan Broadbent feeder door system and Data Ranger. Samples of corn silage, hay, each concentrate mix, WDGS, and each TMR were collected on $\mathrm{d} 5$ of each week of the experiment and stored at $-20^{\circ} \mathrm{C}$ until 
Table 2. Calculated nutrient compositions ${ }^{1}$ for the control, $10 \%$ dried distillers grains with solubles (DDGS), $20 \%$ DDGS, $10 \%$ wet distillers grains with solubles (WDGS), and 20\% WDGS treatment diets fed during the lactation study

\begin{tabular}{|c|c|c|c|c|c|}
\hline \multirow[b]{2}{*}{ Item } & \multicolumn{5}{|c|}{ Diet } \\
\hline & Control & $\begin{array}{l}10 \% \\
\text { DDGS }\end{array}$ & $\begin{array}{l}20 \% \\
\text { DDGS }\end{array}$ & $\begin{array}{l}10 \% \\
\text { WDGS }\end{array}$ & $\begin{array}{l}20 \% \\
\text { WDGS } \\
\end{array}$ \\
\hline & \multicolumn{5}{|c|}{$\longrightarrow(\% \text { of } \mathrm{DM})^{2}$} \\
\hline $\mathrm{CP}$ & 17.0 & 17.0 & 17.0 & 17.0 & 17.0 \\
\hline CP-RDP & 11.8 & 11.3 & 10.8 & 11.3 & 10.8 \\
\hline CP-RUP & 5.3 & 5.7 & 6.2 & 5.7 & 6.2 \\
\hline $\mathrm{NDF}$ & 24.9 & 27.6 & 30.2 & 27.6 & 30.2 \\
\hline $\mathrm{ADF}$ & 16.8 & 17.4 & 18.0 & 17.4 & 18.0 \\
\hline $\mathrm{NFC}$ & 49.8 & 47.1 & 44.3 & 47.1 & 44.3 \\
\hline Ether extract & 2.8 & 3.7 & 4.6 & 3.7 & 4.6 \\
\hline Calcium & 0.88 & 0.82 & 0.80 & 0.82 & 0.80 \\
\hline Phosphorus & 0.36 & 0.34 & 0.37 & 0.34 & 0.37 \\
\hline Magnesium & 0.28 & 0.29 & 0.31 & 0.29 & 0.31 \\
\hline Chloride & 0.52 & 0.54 & 0.55 & 0.54 & 0.55 \\
\hline Potassium & 1.39 & 1.36 & 1.33 & 1.36 & 1.33 \\
\hline Sodium & 0.23 & 0.26 & 0.29 & 0.26 & 0.29 \\
\hline Sulfur & 0.21 & 0.22 & 0.23 & 0.22 & 0.23 \\
\hline Vitamin A (1,000 IU/kg) & 1.40 & 1.40 & 1.40 & 1.40 & 1.40 \\
\hline Vitamin D (1,000 IU/kg) & 0.30 & 0.30 & 0.30 & 0.30 & 0.30 \\
\hline Vitamin E (IU/kg) & 36.8 & 36.8 & 36.8 & 36.8 & 36.8 \\
\hline ME (Mcal/kg of DM) & 2.49 & 2.49 & 2.51 & 2.49 & 2.51 \\
\hline $\mathrm{NE}_{\mathrm{L}}(\mathrm{Mcal} / \mathrm{kg}$ of DM$)$ & 1.56 & 1.58 & 1.58 & 1.58 & 1.58 \\
\hline
\end{tabular}

analysis. Dry matter concentrations of WDGS and corn silage were determined weekly by heating samples for $48 \mathrm{~h}$ in $105^{\circ} \mathrm{C}$ oven. Diets were then adjusted to ensure proper inclusion of components. Weekly, samples of the diet TMR were dried at $105^{\circ} \mathrm{C} \mathrm{DM}$ for $48 \mathrm{~h}$, and used to calculate DMI. Composites were made by period for all feeds sampled and dried for $48 \mathrm{~h}$ at $55^{\circ} \mathrm{C}$ in a Despatch oven (style V-23, Despatch Oven Co., Minneapolis, MN). Composites were then ground to a 4-mm particle size (Wiley mill, model 3; Arthur H. Thomas Co., Philadelphia, PA), and ground further to a 1-mm particle size using an ultracentrifuge mill (Brinkman Instruments Co., Westbury, NY). All feed samples were analyzed for DM, ash, NDF, ADF, lignin, and CP. Dry matter was determined by taking approximately $1 \mathrm{~g}$ of ground sample and drying at $105^{\circ} \mathrm{C}$ for $24 \mathrm{~h}$. Ash was determined by heating samples in a muffle furnace at $450^{\circ} \mathrm{C}$ for $8 \mathrm{~h}$ (Understander et al., 1993). The NDF (Van Soest et al., 1991), ADF (Robertson and Van Soest, 1981), and acid detergent lignin (Lowry et al., 1994) concentrations were determined using the Ankom fiber analysis system (Ankom Technology Corp., Fairport, NY). Alpha-amylase and sodium sulfite were use for the NDF procedure; NDF and ADF were not corrected for ash. Crude protein was determined using the Kjeldahl procedures as described in AOAC (1995). Composites of ground samples of each feed component and TMR were sent to Dairyland Laboratories, Inc. (Arcadia, WI) for analysis of minerals (AOAC, 1995; methods 965.09 and 985.01) with spectroscopic method and Corning 926 Direct Reading Chloride/Salt Analyzer and ether extracts (AOAC, 1995; method 920.39) using the Soxtec 2047 Soxcap in combination with Soxtec extraction systems. Feed fatty acids were prepared as butyl esters in an adapted method of that described by Sukhija and Palmquist (1988) for analysis using gas chromatography (model 6890, Hewlett-Packard, Palo Alto, CA). Using an adaptation of methods described by Loor et al., (2005) samples were analyzed using a flame-ionization detector. The injector port was at $230^{\circ} \mathrm{C}$ with a split ratio of $20: 1$. The column was $100 \mathrm{~m}$, with an i.d. of $0.25 \mathrm{~mm}$ (CP-Sil 88, Varian, Lake Forest, CA). Flow rate was $2.0 \mathrm{~mL} / \mathrm{min}$ of helium. Initial temperature was $50^{\circ} \mathrm{C}$ held for $1 \mathrm{~min}$, then raised to $145^{\circ} \mathrm{C}$ at a rate of $5^{\circ} \mathrm{C} / \mathrm{min}$, and held for $30 \mathrm{~min}$. Temperature was then raised $10^{\circ} \mathrm{C} / \mathrm{min}$ to $190^{\circ} \mathrm{C}$, and held for $30 \mathrm{~min}$. Finally, the temperature was raised $5^{\circ} \mathrm{C} / \mathrm{min}$ to $210^{\circ} \mathrm{C}$, and held for $35 \mathrm{~min}$. The total run per sample was $123.5 \mathrm{~min}$.

Milk samples were collected at all 3 milking times on 2 consecutive days at the end of wk 3 and 4 of each period. Composites of milk samples were made by day on a weight basis and sent to Heart of America DHI Laboratory (Manhattan, KS) for analysis. Milk compositional analysis was conducted according to approved procedures of AOAC (1995). Milk true protein, fat, and lactose were determined using near infrared spectros- 
copy (Bentley 2000 Infrared Milk Analyzer, Bentley Instruments, Chaska, MN). Concentration of MUN was determined using chemical methodology based on a modified Berthelot reaction (ChemSpec 150 Analyzer, Bentley Instruments), and somatic cells were counted using a flow cytometer laser (Somacount 500, Bentley Instruments). Energy-corrected milk was determined using the equation: $[(0.327 \times \mathrm{kg}$ milk $)+(12.95 \times \mathrm{kg}$ fat $)$ $+(7.2 \times \mathrm{kg}$ protein $)]$ (Orth, 1992). Also, composites from $1 \mathrm{~d}$ of wk 4 milk samples were prepared for analysis of milk fatty acid composition using the same procedure as the one used for analysis of feed fatty acids, which was previously described.

Body weights were measured $3 \mathrm{~d}$ at the beginning of the trial and on the last $3 \mathrm{~d}$ of each period. Body condition scores (Wildman et al., 1982) were recorded independently by 3 individuals at the start of the trial and at end of each period.

Rumen fluid samples were taken via an esophageal tube on $2 \mathrm{~d}$ approximately 2 to $3 \mathrm{~h}$ postfeeding in wk 4 of each period. The first $200 \mathrm{~mL}$ expelled from the pump was discarded to minimize contamination by saliva. Ten-milliliter aliquots of rumen fluid were placed immediately in storage tubes and acidified with $2 \mathrm{~mL}$ of $25 \%$ (wt/vol) meta-phosphoric acid. Rumen fluid samples were frozen at $-20^{\circ} \mathrm{C}$ until analysis for ammonia nitrogen concentration (Chaney and Marbach, 1962), and VFA by GLC (model 6890, Hewlett-Packard) using a flame-ionization detector (Ottenstein and Bartley, 1971). The injector port was at $250^{\circ} \mathrm{C}$ with a split ratio of 100:1 with the column described. The column was $15 \mathrm{~m}$ in length and $0.25 \mathrm{~mm}$ in diameter (Supelco, Inc., Bellefonte, PA). Flow rate was $1.3 \mathrm{~mL} / \mathrm{min}$ of helium. Detector and column temperatures were maintained at 225 and $130^{\circ} \mathrm{C}$, respectively.

Period means were determined for all production measurements used for statistical analysis. Statistics were conducted using the MIXED procedure of SAS (SAS Institute, 1999). The experimental model used cow as the experimental unit, and cow (parity) as the random variable. The model included treatment, parity, period, and interactions for treatment by parity, treatment by period, parity by period, and treatment by parity by period. Interactions that were deemed insignificant were removed from the model. Significance was declared at $P<0.05$, and tendency was indicated at $P<0.1$. Orthogonal contrasts were made, based upon experimental objectives, as: 1) control vs. all DG diets, 2) DDGS diets vs. WDGS diets, 3 ) the $10 \%$ concentrations of DG vs. the $20 \%$ concentrations of DG, and 4) interaction of form (wet or dry) and concentration.

\section{RESULTS AND DISCUSSION}

Analysis of DG samples (Table 3) showed that WDGS contained more CP, fiber, and fat than DDGS, whereas mineral content was similar for the $2 \mathrm{DG}$. These differences were reflected in overall diet compositions (Table 4). As previously mentioned, original formulations assumed that both DG were similar except for percentage of DM. As expected, this difference was reflected in the DM content of DDGS and WDGS diets; DM contents of DDGS diets were similar to that of the control, whereas WDGS diets decreased in DM as WDGS inclusion rate increased. The WDGS diets were slightly higher in CP compared with DDGS diets. The 20\% DG diets had greater concentrations of $\mathrm{CP}$ and NDF compared with the $10 \%$ DG diets. As expected, the DG diets contained greater concentrations of fiber and fat than the control diet. The 10\% WDGS diet had a greater concentration of calcium compared with other diets, which is difficult to explain; however; it was not much greater than what the diet was formulated. None of these differences seemed to affect production. The components analyzed for were in the range of the recommended levels of the Dairy NRC (2001). Fatty acid profiles (Table 5) were similar for the 2 DGS. The diets showed some differences depending on the concentration of DGS included. Most notably, the 20\% DG diets had higher concentrations of cis-9 C18:1 and C18:2 than the diets that contained $10 \%$ DG.

No treatment by parity effects were found, indicating that primiparous and multiparous cows responded similarly to these diets. As expected, primiparous cows had less DMI, SCC, feed efficiency, BW, and a tendency for lower yields of milk, ECM, and lactose.

There was a tendency $(P<0.10)$ for cows fed the control diet to consume more than cows fed DG diets (Table 6). No other significant differences were found for DMI with the other contrasts, but, numerically, cows fed $20 \%$ WDGS consumed the least. The tendency for decreased intake by cows fed DG compared with control diet was consistent with some studies (Palmquist and Conrad, 1982; Schingoethe et al., 1999), but most studies (Nichols et al., 1998; Liu et al., 2000; Leonardi et al., 2005) showed no differences in DMI. Decreased intake may be expected in some cases when there is a high inclusion of WDGS because of the high water content of the diet. When diet DM content decreases below 50\%, gut fill may limit DMI, especially with water in combination with fermented feeds (Lahr et al., 1983). This did not appear to be a significant problem in this study, probably attributable to the DM content of forage portion of the diets, although the 20\% WDGS diet was less than 50\% DM. Hippen et al. (2003) observed decreased DMI and milk production when cows were fed $30 \%$ or more of the ration DM as WDGS; such diets contained less than $50 \% \mathrm{DM}$.

Milk production (Table 6) was greater in cows fed DG diets compared with those fed the control diet. This 
Table 3. Nutrient compositions of concentrate mixes, alfalfa hay, corn silage, dried distillers grains with solubles (DDGS), and wet distillers grains with solubles (WDGS) used in TMR during lactation study

\begin{tabular}{|c|c|c|c|c|c|c|c|c|c|}
\hline \multirow[b]{2}{*}{ Item } & \multicolumn{5}{|c|}{ Concentrate $\operatorname{mix}^{1}$} & \multirow[b]{2}{*}{ Hay } & \multirow[b]{2}{*}{$\begin{array}{l}\text { Corn } \\
\text { silage }\end{array}$} & \multirow[b]{2}{*}{ DDGS } & \multirow[b]{2}{*}{ WDGS } \\
\hline & Control & $\begin{array}{l}10 \% \\
\text { DDGS }\end{array}$ & $\begin{array}{l}20 \% \\
\text { DDGS }\end{array}$ & $\begin{array}{l}10 \% \\
\text { WDGS }\end{array}$ & $\begin{array}{l}20 \% \\
\text { WDGS }\end{array}$ & & & & \\
\hline $\mathrm{DM},{ }^{2} \%$ & 87.16 & 87.19 & 87.82 & 86.92 & 86.70 & 87.95 & 29.60 & 88.37 & 31.80 \\
\hline $\mathrm{CP}^{2}$ & 18.78 & 18.62 & 19.17 & 15.09 & 10.15 & 21.60 & 8.36 & 33.16 & 34.42 \\
\hline $\mathrm{NDF}^{2}$ & 10.49 & 14.36 & 19.37 & 10.35 & 9.11 & 39.63 & 48.46 & 31.71 & 36.79 \\
\hline $\mathrm{ADF}^{2}$ & 4.47 & 6.65 & 8.55 & 4.13 & 2.95 & 32.18 & 29.43 & 15.54 & 19.72 \\
\hline Lignin $^{2}$ & - & - & - & - & - & 6.09 & 2.74 & 3.90 & 4.22 \\
\hline Ether extract ${ }^{3}$ & 1.32 & 2.28 & 4.47 & 1.37 & 1.48 & 1.28 & 2.45 & 9.67 & 10.75 \\
\hline $\mathrm{Ash}^{2}$ & 6.46 & 5.74 & 5.91 & 6.77 & 7.21 & 9.65 & 5.34 & 4.17 & 3.88 \\
\hline Calcium $^{3}$ & 0.72 & 0.56 & 0.69 & 1.36 & 1.14 & 1.12 & 0.29 & 0.05 & 0.08 \\
\hline Phosphorus $^{3}$ & 0.27 & 0.32 & 0.40 & 0.23 & 0.22 & 0.25 & 0.25 & 0.61 & 0.66 \\
\hline Magnesium $^{3}$ & 0.24 & 0.24 & 0.27 & 0.23 & 0.27 & 0.35 & 0.27 & 0.27 & 0.27 \\
\hline Potassium $^{3}$ & 0.69 & 0.57 & 0.55 & 0.52 & 0.35 & 1.71 & 1.07 & 0.81 & 0.80 \\
\hline Sulfur ${ }^{3}$ & 0.17 & 0.29 & 0.46 & 0.15 & 0.11 & 0.24 & 0.12 & 0.90 & 0.90 \\
\hline
\end{tabular}

${ }^{1}$ DDGS was included in concentrate mix; WDGS was not included in concentrate mix; it was added when the TMR was mixed.

${ }^{2}$ Average of results of analysis of samples from each period.

${ }^{3}$ Results of analysis of sample composites from whole trial.

finding is consistent with previous research (Owen and Larson, 1991; Powers et al., 1995; Nichols et al., 1998). There were no differences in milk yield for other contrasts. Lack of differences in milk yields between DDGS- and WDGS-fed cows agreed with previous research by Al-Suwaiegh et al. (2002). No differences in milk yields between cows fed 10 and 20\% DG were expected because DG has been shown to usually decrease DMI and milk yield only when fed in excess of
$20 \%$ of total DM (Hippen et al., 2003, 2004; Kalscheur et al., 2004).

Milk fat percentages (Table 6) were similar for control and DG diets but greater from cows fed WDGS diets compared with cows fed DDGS diets. This may reflect slightly greater available fiber content in WDGS; however, Al-Suwaiegh et al. (2002) saw no differences. There was a tendency $(P<0.09)$ for an interaction of form and DGS concentration, meaning that milk from

Table 4. Nutrient compositions of the TMR for the control, $10 \%$ dried distiller grains with solubles (10\% DDGS), $20 \%$ dried distillers grains with solubles (20\% DDGS), $10 \%$ wet distillers grains with solubles $(10 \%$ WDGS), and $20 \%$ wet distiller grains with soluble (20\% WDGS) treatment diets fed during lactation study

\begin{tabular}{|c|c|c|c|c|c|}
\hline \multirow[b]{2}{*}{ Item } & \multicolumn{5}{|c|}{ Diet } \\
\hline & Control & $\begin{array}{l}10 \% \\
\text { DDGS }\end{array}$ & $\begin{array}{l}20 \% \\
\text { DDGS }\end{array}$ & $\begin{array}{l}10 \% \\
\text { WDGS }\end{array}$ & $\begin{array}{l}20 \% \\
\text { WDGS }\end{array}$ \\
\hline $\mathrm{DM},{ }^{1} \%$ & 55.43 & 55.94 & 56.35 & 50.14 & 46.25 \\
\hline $\mathrm{CP}^{1}$ & 16.83 & 16.30 & 17.17 & 17.61 & 17.61 \\
\hline CP-RDP ${ }^{2}$ & 11.68 & 10.79 & 9.48 & 11.20 & 10.25 \\
\hline CP-RUP ${ }^{2}$ & 5.23 & 6.16 & 7.52 & 6.41 & 7.36 \\
\hline $\mathrm{NDF}^{1}$ & 28.27 & 30.68 & 31.24 & 30.35 & 32.37 \\
\hline $\mathrm{ADF}^{1}$ & 17.93 & 19.43 & 19.01 & 19.19 & 20.64 \\
\hline $\operatorname{Lignin}^{1}$ & 2.13 & 2.83 & 3.16 & 2.66 & 2.90 \\
\hline Ether extract ${ }^{3}$ & 2.29 & 3.06 & 4.18 & 3.35 & 3.37 \\
\hline $\mathrm{Ash}^{1}$ & 6.87 & 6.62 & 6.73 & 6.89 & 6.89 \\
\hline Calcium $^{3}$ & 0.78 & 0.72 & 0.70 & 0.86 & 0.76 \\
\hline Phosphorus $^{3}$ & 0.30 & 0.32 & 0.32 & 0.31 & 0.34 \\
\hline Magnesium $^{3}$ & 0.32 & 0.32 & 0.32 & 0.31 & 0.33 \\
\hline Potassium $^{3}$ & 1.14 & 1.10 & 1.01 & 1.08 & 1.02 \\
\hline Sulfur ${ }^{3}$ & 0.20 & 0.27 & 0.33 & 0.28 & 0.34 \\
\hline
\end{tabular}

${ }^{1}$ Average results of analysis of TMR samples from each period.

${ }^{2}$ Calculated using the 2001 Dairy NRC model.

${ }^{3}$ Results of analysis of TMR sample composites from whole trial. 
Table 5. Fatty acid composition of control diet, diets containing 10\% dried distiller grains with solubles (DDGS), 20\% DDGS, 10\% wet distillers grains with solubles (WDGS), and 20\% WDGS, and of the DDGS and WDGS

\begin{tabular}{|c|c|c|c|c|c|c|c|}
\hline \multirow[b]{2}{*}{ Fatty acid ${ }^{1}$} & \multicolumn{5}{|c|}{ Diet } & \multirow[b]{2}{*}{ DDGS } & \multirow[b]{2}{*}{ WDGS } \\
\hline & Control & $\begin{array}{l}10 \% \\
\text { DDGS }\end{array}$ & $\begin{array}{l}20 \% \\
\text { DDGS }\end{array}$ & $\begin{array}{l}10 \% \\
\text { WDGS }\end{array}$ & $\begin{array}{l}20 \% \\
\text { WDGS }\end{array}$ & & \\
\hline & & & $-(\mathrm{g} / 10$ & f total fa & cids) & & \\
\hline C12:0 & 4.17 & 5.94 & 4.98 & 5.44 & 6.10 & 0.78 & 0.60 \\
\hline C14:0 & 4.22 & 3.75 & 3.53 & 4.96 & 5.77 & 2.45 & 7.03 \\
\hline C16:0 & 18.79 & 19.30 & 18.71 & 18.34 & 18.27 & 15.52 & 14.88 \\
\hline C18:0 & 2.78 & 2.54 & 2.60 & 2.52 & 2.33 & 2.38 & 2.21 \\
\hline C18:1 cis-9 & 11.17 & 11.41 & 13.08 & 11.99 & 12.42 & 16.99 & 15.97 \\
\hline C18: 1 cis -11 & 0.44 & 0.42 & 0.40 & 0.42 & 0.39 & 0.42 & 0.43 \\
\hline C18:2 & 35.10 & 35.75 & 39.75 & 36.27 & 37.59 & 52.51 & 48.77 \\
\hline C18:3n-3 & 7.11 & 7.72 & 5.45 & 7.60 & 6.36 & 4.79 & 6.50 \\
\hline C18:3n-6 & 0.62 & 0.80 & 1.32 & 0.75 & 0.67 & 0.42 & 0.60 \\
\hline C20:0 & 4.15 & 3.39 & 2.73 & 3.23 & 2.89 & 1.45 & 1.33 \\
\hline C20:5 & 0.60 & 0.49 & 0.43 & 0.47 & 0.42 & 0.23 & 0.23 \\
\hline C22:5n-3 & 8.65 & 6.25 & 4.84 & 5.79 & 4.75 & 0.10 & 0.10 \\
\hline C22:4 & 0.28 & 0.11 & 0.18 & 0.13 & 0.14 & 0.18 & 0.20 \\
\hline $\mathrm{C} 22: 6$ & 0.54 & 0.42 & 0.42 & 0.50 & 0.55 & 0.25 & 0.23 \\
\hline Others $^{2}$ & 1.37 & 1.71 & 1.59 & 1.58 & 1.35 & 1.53 & 0.92 \\
\hline
\end{tabular}

${ }^{1}$ Expressed as number or carbons: number of double bonds.

${ }^{2}$ Others $=$ sum of C14:1, C16:1, C20:1, C20:2, C20:3, C22:0, C22:1, C22:3, C24:0, C24:1, and C22:5n-6.

cows fed 10\% DDGS diets tended to have lower milk fat percentages than milk from cows fed 20\% DDGS, whereas the opposite was true for WDGS-fed cows. Milk fat yields were greater $(P<0.04)$ for cows fed DG diets than for cows fed control diets. This difference was similar to differences in milk yield.

Milk fatty acid profiles (Table 7) varied between treatments. Milk fat from cows fed the control diet had greater $(P<0.01)$ concentrations of C10:0, C12:0, C14:0, C16:0, and a tendency $(P<0.06)$ for more C16:1 than milk from cows fed DG. However, cows fed the control diet also had decreased $(P<0.01)$ concentrations of C18:0, trans-9 C18:1, trans-11 C18:1, cis-9 C18:1, C18:2, C20:0, and both conjugated linoleic acids (CLA). The differences in the concentrations of these fatty acids are reflected in differences between the summa-

Table 6. Dry matter intake, milk yield and composition, efficiency calculations, and body characteristics for cows fed control diet, and diets containing $10 \%$ dried distillers grains with solubles (DDGS), 20\% DDGS, $10 \%$ wet distillers grains with solubles (WDGS), and 20\% WDGS

\begin{tabular}{|c|c|c|c|c|c|c|c|c|c|c|}
\hline \multirow[b]{3}{*}{ Item } & \multicolumn{5}{|c|}{ Diet } & \multirow[b]{3}{*}{ SEM } & \multirow{2}{*}{\multicolumn{4}{|c|}{ Contrast $^{1}(P$-value $)$}} \\
\hline & & $10 \%$ & $20 \%$ & $10 \%$ & $20 \%$ & & & & & \\
\hline & Control & DDGS & DDGS & WDGS & WDGS & & A & $\mathrm{B}$ & $\mathrm{C}$ & $\mathrm{D}$ \\
\hline DMI, kg/d & 23.4 & 22.8 & 22.5 & 23.0 & 21.9 & 0.86 & 0.09 & 0.65 & 0.16 & 0.34 \\
\hline Milk, kg/d & 39.8 & 40.9 & 42.5 & 42.5 & 43.5 & 1.49 & 0.02 & 0.13 & 0.12 & 0.73 \\
\hline Fat, $\%$ & 3.23 & 3.16 & 3.28 & 3.55 & 3.40 & 0.14 & 0.25 & $<0.01$ & 0.88 & 0.09 \\
\hline Fat, kg/d & 1.28 & 1.32 & 1.39 & 1.44 & 1.43 & 0.06 & 0.04 & 0.10 & 0.53 & 0.36 \\
\hline Protein, \% & 3.05 & 3.01 & 3.02 & 3.11 & 3.06 & 0.07 & 0.97 & $<0.05$ & 0.70 & 0.41 \\
\hline Protein, kg/d & 1.20 & 1.22 & 1.29 & 1.29 & 1.33 & 0.04 & 0.01 & 0.05 & 0.08 & 0.64 \\
\hline Lactose, \% & 4.91 & 4.92 & 4.93 & 4.95 & 4.96 & 0.04 & 0.46 & 0.40 & 0.82 & 0.98 \\
\hline Lactose, $\mathrm{kg} / \mathrm{d}$ & 1.94 & 2.02 & 2.09 & 2.11 & 2.16 & 0.07 & $<0.01$ & 0.10 & 0.17 & 0.84 \\
\hline MUN, mg/dL & 13.30 & 12.59 & 12.36 & 12.94 & 14.09 & 0.30 & 0.25 & $<0.01$ & 0.06 & $<0.01$ \\
\hline $\mathrm{SCC}, 10^{5} / \mathrm{mL}$ & 1.31 & 1.40 & 1.48 & 1.13 & 1.17 & 0.52 & 0.97 & 0.39 & 0.85 & 0.95 \\
\hline $\mathrm{ECM},{ }^{2} \mathrm{~kg} / \mathrm{d}$ & 38.4 & 39.6 & 41.3 & 41.7 & 42.0 & 1.18 & 0.01 & 0.12 & 0.29 & 0.43 \\
\hline Feed efficiency ${ }^{3}$ & 1.70 & 1.79 & 1.87 & 1.84 & 1.92 & 0.65 & $<0.01$ & 0.27 & 0.06 & 0.95 \\
\hline $\mathrm{BW}, \mathrm{kg}$ & 652.2 & 650.8 & 654.3 & 653.0 & 655.5 & 14.34 & 0.70 & 0.51 & 0.24 & 0.84 \\
\hline $\mathrm{BCS}$ & 3.30 & 3.31 & 3.33 & 3.35 & 3.35 & 0.11 & 0.48 & 0.49 & 0.71 & 0.79 \\
\hline
\end{tabular}

${ }^{1}$ Contrast $\mathrm{A}=$ control diet vs. DG diets; Contrast $\mathrm{B}=$ DDGS diets vs. WDGS diets; Contrast $\mathrm{C}=10 \%$ inclusion diets vs. $20 \%$ inclusion diets; Contrast $\mathrm{D}=$ interaction of form (dried vs. wet) and inclusion rate (10 vs. $20 \%)$.

${ }^{2} \mathrm{ECM}=[(0.327 \times \mathrm{kg}$ milk $)+(12.95 \times \mathrm{kg}$ fat $)+(7.2 \times \mathrm{kg}$ protein $)]($ Orth, 1992).

${ }^{3}$ Feed efficiency $=$ ECM/DMI. 
Table 7. Milk fatty acid composition for cows fed control diet, and diets containing 10\% dried distillers grains with solubles (DDGS), 20\% DDGS, $10 \%$ wet distillers grains with solubles (WDGS), and 20\% WDGS

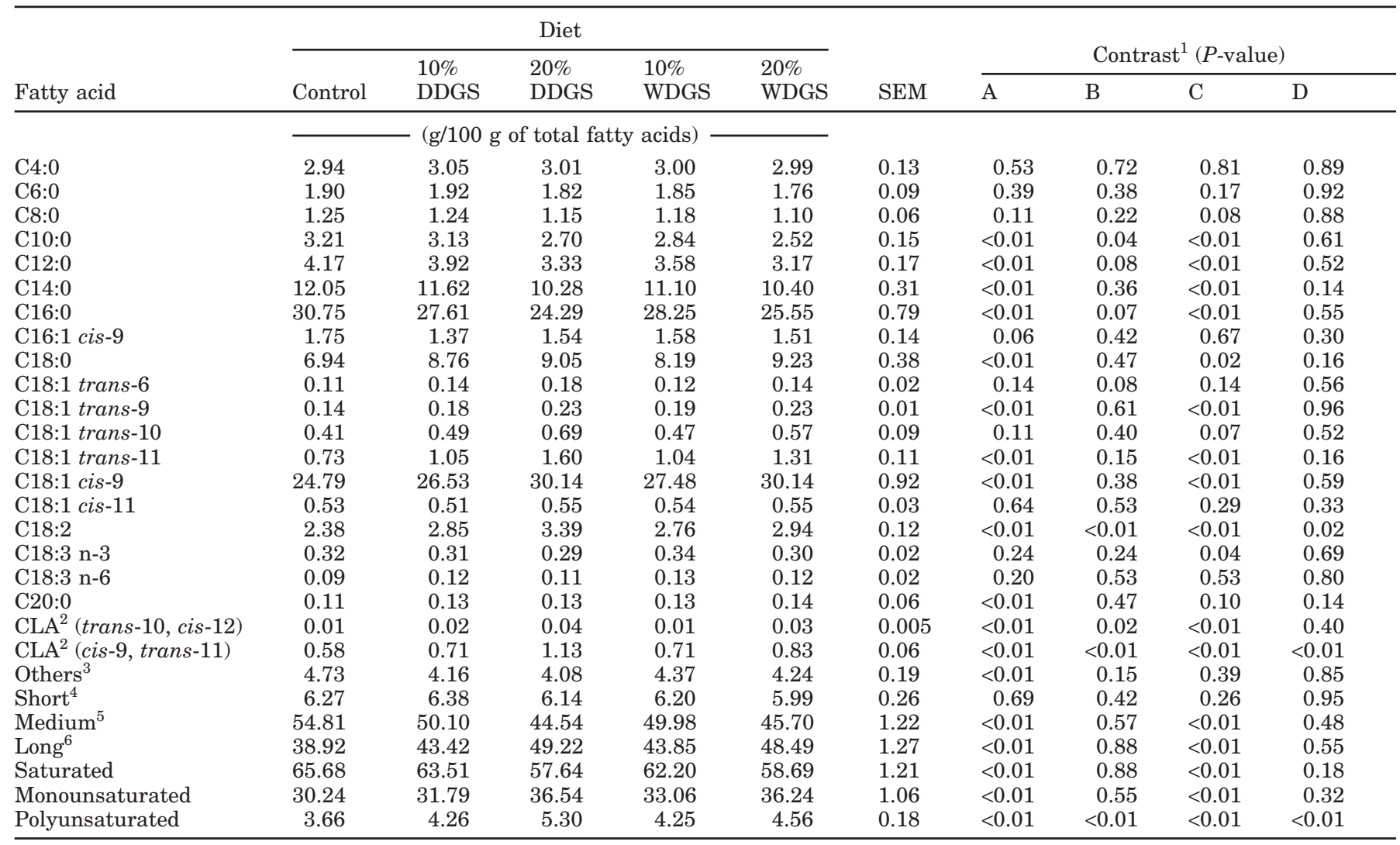

${ }^{1}$ Contrast $\mathrm{A}=$ control diet vs. DG diets; Contrast B = DDGS diets vs. WDGS diets; Contrast $\mathrm{C}=10 \%$ inclusion diets vs. $20 \%$ inclusion diets; Contrast $\mathrm{D}=$ interaction of form (dried vs. wet) and inclusion rate (10 vs. $20 \%)$.

${ }^{2} \mathrm{CLA}=$ Conjugated linoleic acid.

${ }^{3}$ Others = C5:0, C12:1, C14:1, C15:0, C17:0, C17:1, C19:0, C20:1, C20:2, C20:3, C22:0; C22:1, C22:3, C24:0, C 20:5, C22:4, C22:5, and C22:6.

${ }^{4}$ Short $=\mathrm{C} 4: 0$ to $\mathrm{C} 8: 0$.

${ }^{5}$ Medium $=\mathrm{C} 10: 0$ to $\mathrm{C} 16: 1$.

${ }^{6}$ Long $=\mathrm{C} 17: 0$ to $\mathrm{C} 22: 6$

tions of medium, long, saturated, and unsaturated fatty acids. Relative to the control, feeding DG did not significantly increase trans-10 C18:1, contrary to the observation of Leonardi et al. (2005), but increased trans$11 \mathrm{C} 18: 1$ and cis-9, trans-11 CLA, as they observed. There were very few differences in milk fatty acids between cows fed diets with DDGS or WDGS. Milk from cows fed WDGS had lower concentrations $(P<0.04)$ of C10:0, C18:2, cis-9, trans-11 CLA, and tended $(P<0.08)$ to have lower trans-6 C18:1, compared with cows fed diets containing DDGS. Concentrations of DG in the diet had many affects on milk fatty acid composition. Milk from cows fed 10\% DG had greater $(P<0.01)$ concentrations of C10:0, C12:0, C14:0, C16:0, n-3 C18:3, and a tendency $(P<0.08)$ for more C8:0, than milk from cows fed $20 \%$ DG diets. However, milk from cows fed $20 \%$ DG diet had greater $(P<0.02)$ concentrations of
C18:0, most of the C18:1 isomers, and both CLA, and a tendency $(P<0.10)$ for more C20:0. These differences are also reflected in the differences of the sums of short, medium, long, saturated, and unsaturated fatty acids. The differences could be attributed to the increased C18:2 and cis-9 C18:1 and decreased C16:0 in the diets (Table 5). There were 2 significant $(P<0.02)$ interactions of form and concentration of DG in the diets; C18:2 and cis-9, trans-11 CLA were less different between cows fed 10 vs. $20 \%$ WDGS compared with the cows fed 10 vs. $20 \%$ DDGS. These 2 interactions led to a significant $(P<0.01)$ interaction of the sum of polyunsaturated fatty acids. The differences in fatty acid profiles between the 20\% WDGS and control diet agreed with a previous study by Schingoethe et al. (1999), which compared feeding 30\% WDGS to replace soybean meal and half the corn in the concentrate mix. However, 
Table 8. Ruminal ammonia concentrations and VFA concentrations for cows fed control diet, and diets containing $10 \%$ dried distillers grains with solubles (DDGS), 20\% DDGS, 10\% wet distillers grains with solubles (WDGS), and 20\% WDGS

\begin{tabular}{|c|c|c|c|c|c|c|c|c|c|c|}
\hline \multirow[b]{3}{*}{ Item } & \multicolumn{5}{|c|}{ Diet } & \multirow[b]{3}{*}{ SEM } & \multirow{2}{*}{\multicolumn{4}{|c|}{ Contrast $^{1}(P$-value $)$}} \\
\hline & & $10 \%$ & $20 \%$ & $10 \%$ & $20 \%$ & & & & & \\
\hline & Control & DDGS & DDGS & WDGS & WDGS & & $\mathrm{A}$ & B & $\mathrm{C}$ & $\mathrm{D}$ \\
\hline $\mathrm{NH}_{3}, \mathrm{mg} / \mathrm{dL}$ & 4.8 & 3.8 & 3.1 & 3.9 & 5.0 & 0.46 & 0.08 & 0.02 & 0.56 & 0.04 \\
\hline \multirow[t]{2}{*}{ Total VFA, mM } & 64.4 & 60.7 & 51.8 & 61.4 & 68.4 & 6.22 & 0.55 & 0.13 & 0.86 & 0.16 \\
\hline & \multicolumn{5}{|c|}{$(\mathrm{mmol} / 100 \mathrm{mmol})^{2}$} & & & & & \\
\hline Acetate & 59.0 & 58.1 & 57.3 & 58.8 & 60.6 & 0.83 & 0.69 & $<0.01$ & 0.38 & 0.03 \\
\hline Propionate & 27.2 & 28.1 & 29.2 & 29.1 & 27.6 & 0.92 & 0.12 & 0.69 & 0.76 & 0.06 \\
\hline Butyrate & 10.6 & 10.9 & 11.0 & 9.4 & 9.1 & 0.35 & 0.21 & $<0.01$ & 0.74 & 0.57 \\
\hline Isovalerate & 1.5 & 1.4 & 1.1 & 1.3 & 1.3 & 0.11 & $<0.01$ & 0.62 & 0.12 & 0.23 \\
\hline Valerate & 1.5 & 1.5 & 1.4 & 1.4 & 1.4 & 0.09 & 0.47 & 0.67 & 0.89 & 0.33 \\
\hline Acetate:propionate & 2.2 & 2.1 & 2.0 & 2.1 & 2.2 & 0.10 & 0.11 & 0.19 & 0.66 & 0.06 \\
\hline
\end{tabular}

${ }^{1}$ Contrast $\mathrm{A}=$ control diet vs. DG diets; Contrast $\mathrm{B}=$ DDGS diets vs. WDGS diets; Contrast $\mathrm{C}=10 \%$ inclusion diets vs. $20 \%$ inclusion diets; Contrast $\mathrm{D}=$ interaction of form (dried vs. wet) and inclusion rate (10 vs. $20 \%)$

${ }^{2}$ No isobutyrate was detected.

the C18:1 isomers and CLA were not reported in that study so those results can not be compared. However, differences in C18:1 isomers and cis-9, trans-11 CLA concentrations agreed with most of the differences found between cows fed 0\% DG diets and 10\% DG diets in a study by Leonardi et al. (2005).

Milk protein percentages (Table 6 ) were similar for control and DG diets but greater $(P<0.05)$ when cows were fed WDGS diets compared with DDGS diets. Milk protein yield was greater $(P<0.01)$ for the DG cows compared with control cows, was greater when cows were fed WDGS vs. DDGS, and tended $(P<0.08)$ to be greater for cows fed 20 vs. $10 \%$ DG. For MUN, there was an interaction of form and inclusion rate; with $20 \%$ WDGS fed cows having the greatest MUN and the $20 \%$ DDGS fed cows the least. The MUN concentrations may also indicate that none of the diets contained an excess or a deficiency of protein.

No differences were found in milk lactose percentage (Table 6), and variation in lactose yield can be attributed to differences in milk yields. Somatic cell counts were within the normal range, indicating no major problems with mastitis and no differences among treatments were detected.

Yields of ECM (Table 6) were greater for cows fed DG compared with cows fed the control diet, but there were no differences for ECM among DG diets. Feed efficiency, expressed as ECM divided by DMI, increased when cows were fed DG diets. This reflected slightly greater DMI of the control diet and greater ECM for cows fed DG diets. Feed efficiency was similar for WDGS and DDGS diets, but there was a trend $(P<$ 0.06 ) for greater efficiency when cows were fed $20 \%$ DG diets. There were no significant treatment effects on
BCS or BW (Table 6). The average BW was around 653 $\mathrm{kg}$ and the average BCS was 3.3 for all treatments.

Analysis of rumen content samples (Table 8) helped explain some of the production results. Concentrations of $\mathrm{NH}_{3}-\mathrm{N}$ were less than observed in other research with DG (Nichols et al., 1998; Schingoethe et al., 1999; Liu et al., 2000) possibly because of sampling technique. Sampling rumen fluid via esophageal tube is less precise than sampling through a fistula, but differences between treatments can still be observed. Animals were fed ad libitum, and feed was available at all times; thus, these samples were meant to be a quick view of the ruminal fermentation. The time was chosen because animals tend to eat a larger meal after being given fresh feed, and samples were meant to be taken at peak of carbohydrate fermentation. Because the NDF in DG replaced starch in the control, it is possible that VFA proportions may be influenced by diet.

Ammonia nitrogen concentrations tended $(P<0.08)$ to be greater in cows fed control vs. DG diets. This may be because of the greater portion of soybean meal protein in the control diet, which is more degradable in the rumen than protein in DG (Firkins et al., 1984; Schingoethe et al., 1999; Kleinschmit et al., 2005). Ruminal ammonia concentrations were greater in cows fed WDGS than in cows fed DDGS, especially the $20 \%$ WDGS diet. Cows fed the 20\% DDGS diet had the lowest ruminal ammonia concentrations (significantly less than cows fed $10 \%$ DDGS). This was probably because of the greater concentration of RUP in DDGS, as found in a companion study by Kleinschmit et al. (2005) in which DG sources "E" and "W" were the same DDGS and WDGS, respectively, as used in this trial. The cows fed 10\% WDGS had lower ammonia concentrations 
than the cows fed the 20\% WDGS diet, which had the greatest concentration. This may reflect a greater degradability, but less use for microbial protein synthesis, perhaps because a portion of the ground corn was replaced by WDGS. Thus, with 20\% WDGS diets, there may not have been enough readily fermentable carbohydrates to match degradation of protein, and this led to greater ammonia concentrations. Variations in rumen ammonia corresponded with the MUN variations discussed.

Total VFA concentrations were similar for all diets in agreement with Al-Suwaiegh et al. (2002); however, some studies found total VFA concentrations to be less when cows are fed diets containing DG (Nichols et al., 1998; Schingoethe et al., 1999). Acetate concentrations were similar among cows fed control and DG, and in cows fed 10 vs. $20 \%$ DG diets. Nichols et al. (1998) found that acetate concentrations were greater and Schingoethe et al. (1999) found that acetate tended $(P<0.1)$ to be greater when cows were fed diets containing DG compared with soybean meal. Unlike the study conducted by Al-Suwaiegh et al. (2002), molar percentages of acetate were greater in cows fed WDGS diets compared with cows fed the DDGS diets. Greater acetate proportion when cows were fed WDGS diets may have resulted from greater degradability of NDF in the WDGS (Kleinschmit et al., 2005); however, differences were numerically small, so the biological significance of these differences was questionable. In agreement with Al-Suwaiegh et al. (2002), there were no differences among treatments for propionate concentrations; however, there was a trend $(P<0.11)$ for cows fed the control diet to have slightly greater acetate to propionate ratio than cows fed DG diets, and there were no differences due to DG concentration or form. Nichols et al. (1998) found that propionate tended $(P<0.1)$ to be less and Schingoethe et al. (1999) found it was less in cows fed DG compared with soybean meal. Nichols et al. (1998) found a similar trend in acetate to propionate ratio as in this study. Butyrate concentrations were greater in cows fed the DDGS diets compared with cows fed WDGS diet, in an inverse ratio to acetate. This result contrasted results of Al-Suwaiegh et al. (2002), who found no differences between VFA compositions for cows fed diets containing DDGS vs. WDGS. There were some differences and trends between treatments for isovalerate and valerate concentration; however, overall numbers were so close that biological significance of any of these differences was questionable.

\section{CONCLUSIONS}

Based upon the findings of this research, both DDGS and WDGS can replace a portion of the ground corn and soybean meal commonly fed to dairy cattle and maintain or enhance lactational performance. Cows fed DG had greater feed efficiency and milk yield, and maintained milk component concentrations, with increased yields of milk components. When comparing lactation performance of cows fed diets containing DDGS or WDGS, there were greater concentrations of milk fat, protein, and MUN in milk from cows fed WDGS. There were no significant production differences between cows fed 10\% DG and 20\% DG, except for the composition of the milk fatty acid profile. In conclusion, either WDGS or DDGS can be used to feed dairy cows at $10 \%$ or $20 \%$ of diet DM with similar production. However, there is an advantage to feeding WDGS because of the increases in milk fat and protein.

\section{ACKNOWLEDGMENTS}

Appreciation is extended to the farm crew at the South Dakota State University Dairy Research Unit (D. D. Rennich, manager) for care of the cows and assistance with data collection. This research was partially supported by funds from the South Dakota Agricultural Experiment Station project no. H-272 and the Michigan Biotechnology Institute (MBI) through USDA/ARS project no. 483014.

\section{REFERENCES}

Al-Suwaiegh, S., K. C. Fanning, R. J. Grant, C. T. Milton, and T. J. Klopfenstein. 2002. Utilization of distillers grains from the fermentation of sorghum or corn in diets for finishing beef and lactating dairy cattle. J. Anim. Sci. 80:1105-1111.

AOAC. 1995. Official Methods of Analysis. 16th ed. Association of Official Analytical Chemists, Arlington, VA.

Chaney, A. L., and E. P. Marbach. 1962. Modified reagents for determination of urea and ammonia. Clin. Chem. 8:130-132.

Firkins, J. L., L. L. Berger, G. C. Fahey, Jr., and N. R. Mechen. 1984. Ruminal nitrogen degradability and escape of wet and dry distillers grains and wet and dry corn gluten feeds. J. Dairy Sci. 67:1936-1944.

Ham, G. A., R. A. Stock, T. J. Klopfenstein, E. M. Larson, D. H. Shain, and R. P. Huffman. 1994. Wet corn distillers by-products compared with dried corn distillers grains with solubles as a source of protein and energy for ruminants. 1994. J. Anim. Sci. 72:3246-3257.

Hippen, A. R., K. F. Kalscheur, D. J. Schingoethe, and A. D. Garcia. 2004. Increasing inclusion of dried corn distillers grains in dairy cow diets. J. Dairy Sci. 87(Suppl. 1):1965. (Abstr.)

Hippen, A. R., K. N. Linke, K. F. Kalscheur, D. J. Schingoethe, and A. D. Garcia. 2003. Increased concentrations of wet corn distillers grains in dairy cow diets. J. Dairy Sci. 86(Suppl. 1):340. (Abstr.)

Kalscheur, K. F., A. L. Justin, A. R. Hippen, and D. J. Schingoethe. 2004. Increasing wet distillers grains in diets of dairy cows on milk production and nutrient utilization. J. Dairy Sci. 87(Suppl. 1):465. (Abstr.)

Kleinschmit, D. H., J. M. Ladd, D. J. Schingoethe, K. F. Kalscheur, and A. R. Hippen. 2005. Ruminal and Intestinal digestibility of distillers grain with solubles varies by source. J. Dairy Sci. 88(Suppl 1):186. (Abstr.)

Lahr, D. A., D. E. Otterby, D. G. Johnson, J. G. Linn, and R. G. Lundquist. 1983. Effects of moisture content of complete diets on 
feed intake and milk production by cows. J. Dairy Sci. 66:1891-1900.

Leonardi, C., S. Bertics, and L. E. Armentano. 2005. Effect of increasing oil from distillers grains or corn oil on lactation performance. J. Dairy Sci. 88:2820-2827.

Liu, C., D. J. Schingoethe, and G. A. Stegeman. 2000. Corn distillers grains versus a blend of protein supplements with or without ruminally protected amino acids for lactating cows. J. Dairy Sci. 83:2075-2084.

Loor, J. J., A. Ferlay, A. Ollier, K. Ueda, M. Doreou, and Y. Chilliard. 2005. High concentrate diet and polyunsaturated oils alter trans and conjugated isomer in bovine rumen, blood and milk. J. Dairy Sci. 88:3986-3999.

Lowry, J. B., L. L. Conlan, A. A. Schlink, and C. S. McSweeny. 1994. Acid detergent dispersible lignin in tropical grasses. J. Food Agric. 65:41-50.

Nichols, J. R., D. J. Schingoethe, H. A. Maiga, M. J. Brouk, and M. S. Piepenbrink. 1998. Evaluation of corn distiller grains and ruminally protected lysine and methionine for lactating dairy cows. J. Dairy Sci. 81:482-491.

NRC. 2001. Nutrient Requirements of Dairy Cattle. 7th rev. ed. Natl. Acad. Sci., Washington, DC.

Orth, R. 1992. Sample day and lactation report. DHIA 200 Fact Sheet A-2. Mid-states DRPC, Ames, IA.

Ottenstein, D. M., and D. A. Bartley. 1971. Separation of free acids C2 - C5 in dilute aqueous solution column technology. J. Chromatogr. Sci. 9:673-681.

Owen, F. G., and L. L. Larson. 1991. Corn distillers dried grains versus soybean meal in lactation diets. J. Dairy Sci. 74:972-979.
Palmquist, D. L., and H. R. Conrad. 1982. Utilization of distillers dried grains plus solubles by dairy cow in early lactation. J. Dairy Sci. 65:1729-1733.

Powers, W. J., H. H. Van Horn, B. Harris, Jr., and C. J. Wilcox. 1995. Effects of variable sources of distiller dried grain plus solubles on milk yield and composition. J. Dairy Sci. 78:388-396.

Robertson, J. B., and P. J. Van Soest. 1981. The detergent system of analysis and its application to human foods. Pages 123-158 in The Analysis of Dietary Fiber in Food. W. P. T. James and O. Theander, ed. Marcel Dekker Inc., New York, NY.

SAS Institute. 1999. SAS User's Guide. Statistics, Version 8.01 ed. SAS Institute, Inc., Cary, NC.

Schingoethe, D. J. 2001. Using distillers grain in the dairy ration. Pages 10-17 in Proc. Natl. Corn Growers Association Ethanol Coproducts Workshop "DDGS: Issues to Opportunities." Lincoln, NE. Natl. Corn Growers Assoc., St. Louis, MO.

Schingoethe, D. J., M. J. Brouk, and C. P. Birkelo. 1999. Milk production and composition from cows fed wet corn distillers grains. J. Dairy Sci. 82:574-580.

Sukhija, P. S., and D. L. Palmquist. 1988. A rapid method for determination of total fatty acid content and composition of feedstuffs and feces. J. Agric. Food Chem. 36:1202-1206.

Understander, D., D. R. Mertens, and N. Thiex. 1993. Forage analysis procedures. National Forage Testing Association, Omaha, NE.

Van Soest, P. J., J. B. Robertson, and B. A. Lewis. 1991. Methods for dietary fiber, neutral detergent fiber, and nonstarch polysaccharides in relation to animal nutrition. J. Dairy Sci. 74:35833597.

Wildman, E. E., G. M. Jones, P. E. Wagner, R. L. Boman, H. F. Troutt, Jr., and T. N. Lesch. 1982. A dairy cow body condition scoring system and its relationship to standard production characteristics. J. Dairy Sci. 65:495-501. 